\title{
DIFFERENTIAL DIAGNOSIS: TREPANATION
}

John W. Verano ${ }^{1}$

Tulane University

1. Department of Anthropology, Tulane University, New Orleans, LA 70118 USA. Verano@tulane.edu 


\begin{abstract}
Trepanation is the scraping, cutting, or drilling of an opening (or openings) into the neurocranium. World surveys reveal that a number of ancient cultures experimented with cranial surgery, and that in some areas these practices continued into modern times. Archaeological discoveries of possible trepanations continue to be made, often from geographic areas or time periods from which the practice was not previously known. Unfortunately, most of these reports describe single crania with healed defects interpreted as trepanations. When evaluating a possible trepanation in a skull that lacks medical history or comes from an archaeological context where there is no other evidence that such operations were performed, a thorough differential diagnosis is essential. Identification of unhealed trepanations is a relatively straightforward exercise, since tool marks provide direct evidence of surgical intervention. A confident diagnosis is more difficult in healed defects of the skull, where the mechanism that produced an opening may be obscured by bone remodeling. There are many possible causes of defects of the skull vault, including congenital and developmental anomalies, trauma, infection, neoplasm, and taphonomic damage. For this reason, a careful differential diagnosis is essential for identifying surgical intervention and distinguishing it from cranial defects caused by other mechanisms.
\end{abstract}

Key Words:

Trepanation; Trephination; Ancient Surgery; Cranial Defects; Differential Diagnosis 


\section{Introduction}

Trepanation, or trephination, is the scraping, cutting, or drilling of an opening (or openings) into the skull. Despite the risk of brain injury, hemorrhage, and infection, trepanation was surprisingly widespread in prehistory, dating back to at least 5,000 BC in Europe and to around 500 BC in the New World (Verano 2016). New cases continue to be reported in the paleopathological and archaeological literature, with particular attention given to possible trepanations found in geographic regions or time periods without prior evidence of such practices (Ferembach 1962; Alt et al. 1997; Lillie 1998; Han and Cheng 2007; Crubézy et al. 2001; Bazarsad 2003; Murphy 2003; Lv et al 2013). At issue with any new discovery is the reliability of the diagnosis, particularly given the variety of mechanisms other than trepanation that can produce defects in the neurocranium. Careful differential diagnosis is essential for properly distinguishing between trepanations and defects resulting from congenital and developmental anomalies, trauma, infection, neoplasm, and taphonomic damage (Bennike 2003; Campillo 2007; Kaufman, Whitaker and McTavish 1997; Merbs 1989). Healed cranial defects present the greatest interpretive challenge, since the causative mechanism may be obscured by bone remodeling. With reference to such cases, Donald Ortner has noted: "One of the factors contributing to the controversy is the difficulty of conclusively identifying a trephination in an archeological specimen" (Ortner 2003: 170). This problem continues, particularly when one is faced with a possible trepanation from a geographic area or time period where other convincing cases have not been found. Following a brief review of trepanation methods and their diagnostic features, this article will review the various categories of cranial defects that may be incorrectly diagnosed as trepanations. It will then examine specific examples from archaeological contexts where a diagnosis may or may not be straightforward.

2. Trepanation: Definition and Diagnostic Features

Trepanation can be performed by a variety of methods, and with various tools. The most commonly reported methods are 1) scraping, where the outer table and diploe are gradually abraded away, exposing the inner table, which may be scraped through or carefully broken out, 2) grooving, where a circular or oval portion of bone is circumscribed by repeated cuts until a disc of bone can be removed, 3) intersecting linear cuts, usually defining a rectangular piece of bone that is also removed, 4) boring and cutting, where a circle of small drilled holes are made and the bone bridges between them cut to allow removal of a disc of bone (Figure 1). Additional methods include small clusters of drilled holes (a rare technique) and the classic "burr hole" made with a crown trepan or a modern drill. Scraping is the most common method seen in prehistoric crania, whereas linear cutting, boring and cutting, and drilling are the least common (Lisowski 1967; Campillo 2007). It should be noted, however, that in trepanations showing long term healing evidence of the specific method may be obscured by bone remodeling and retraction of the edges of trepanation openings (Lastres and Cabieses 1960). It is primarily in cases where there is no visible bone reaction or only short term healing that different 
trepanation techniques can be distinguished with confidence, based on tool marks and unremodeled margins of openings.

Trepanations showing bone reaction around their margins indicate that the operation was done in a living patient. Openings with no sign of bone reaction indicate that the patient died during or shortly (perhaps as long as a week) after surgery (Barbian and Sledzik 2008), or alternatively that the opening was made postmortem, either to collect a bone disc (e.g., a roundel) or to practice trepanation technique (Prunières 1874; Piggot 1940; Kurin 2013). Characteristic features of bone healing are important in recognizing short term survival. Early signs include evidence of hyperemia and osteoclastic activity around the margins of a trepanation opening Typically an area of necrotic bone surrounds the trepanation site, due to loss of blood supply with removal of the periosteum (Stewart 1956). The outer margin of necrotic bone is marked by osteoclastic pitting, described by Barbian and Sledzik (2008) as the "line of demarcation"(Figure 2). With continued healing there is closing off of the exposed diploë and retraction of the margins of the opening. It is important to note that trepanation holes retract rather than close up, as is sometimes mistakenly assumed. Closure of even small surgical burr holes is rare, as judged from modern cases with known post-operative periods (Sauer and Dunlap 1985; Nerlich et al. 2003). The following sections describe cranial defects that can be misdiagnosed as trepanations, and which should be considered in a differential diagnosis.

\section{Differential Diagnosis of Cranial Defects}

3.1 Defects Reflecting Normal Cranial Anatomy

In infants and children, spaces are normally present between developing vault bones. Fontanelles (fibrous tissue found between developing vault bones in infants), may be confused in archaeological material for a trepanation, in particular the large anterior fontanelle, located between the developing halves of the left and right frontal bones and the parietal bones. Given that the fontanelles are well known anatomical features of the developing cranium, confusion with trepanations is unlikely, unless they are unusually large or remain open longer than normal (Figure 3a,b). Any fragment of a juvenile cranium that shows a portion of a smoothedged vault defect should be evaluated with caution.

\subsection{Failure of Normal Ossification}

Defects in the cranium may result from failure to ossify normally during growth and development. An example is partial or complete dysostosis, where cranial bones do not properly unite at the sutures, as in cleidocranial dysostosis or hydrocephalus. Small defects may also be produced by a bulging outward of the meninges (meningocoele), creating a smooth, round depression between sutures (Kaufman, Whitaker and McTavish 1997). A common location for such defects is along the sagittal suture at or just posterior to bregma, where the coronal and sagittal sutures meet (Figure 4a,b). Stewart (1975a) reported a case of a prehistoric skull with a meningeocoele that was misdiagnosed as a trepanation. A more recent report of a cranium claimed as one of the earliest trepanations from Europe (Lillie 
1998: Figure 2) illustrates a similar lesion, but does not consider meningocoele as a differential diagnosis. Given its location and shape, and the fact that the cranium is a single isolated specimen in a region and time period without other convincing evidence of cranial surgery, meningocoele should be considered as a more likely diagnosis. Cranial inclusion (dermoid) and epidermal cysts also produce smoothwalled depressions and defects of the cranial vault that could be confused with healed trepanations (Barnes, 2012; Klaus and Byrnes 2013; Ortner 2003).

\subsubsection{Parietal Fenestrae (Enlarged Parietal Foramina)}

Although not all authors distinguish between the parietal fenestrae and enlarged parietal foramina (e.g., Barnes 1994, 2012), Kaufman, Whitaker and McTavish (1997: 197) argue that the former term is the correct one, since parietal fenestrae are sometimes found near normal parietal foramina. Parietal fenestrae are usually bilateral and typically oval in shape, although in some cases they are only narrow slits (Figure 5). Large fenestrae have been mistaken for healed trepanations (Goldsmith 1945), although their bilateral symmetry and the fact that they are usually found near the location of the parietal foramina should aid in their proper identification. The specific cause of parietal fenestrae is not known, although they have been demonstrated to run in families, as in the case of "Catlin Marks" (Goldsmith, ibid).

\subsection{Biparietal Thinning}

Biparietal thinning is a condition characterized by gradual thinning of the posterior-superior region of the parietal bones and loss of diploic bone, creating visible depressions (Figure 6a,b). Pronounced cases may show small openings through the inner table, although postmortem breakage of the thinned bone is the most common cause of these. Biparietal thinning is most frequently seen in older adults (Cederlund et al. 1982; Wilms et al. 1983) although some cases have been reported in children (Barnes 1994, 2012). Examples of parietal thinning have sometimes been misdiagnosed as healed trepanations (Lisowski 1967: Figure 2). As in the case of parietal fenestrae, the location, symmetry, and characteristic shape of these depressions should distinguish them from healed trepanations, especially when found in a single cranium from a large skeletal sample that shows no other convincing examples of trepanation.

\section{Defects of Diverse Origin}

4.1 Infection

Infection (osteomyelitis) of the vault bones of the skull caused by pyogenic bacteria, tuberculosis, or treponemal disease can produce defects that may be misdiagnosed as trepanations (Kaufman, Whitaker and McTavish 1997; Ortner 2003). If the infection was active at the time of death, the margins of these defects will be porous and ragged, but if healed, they will be remodeled, and could be confused with healed trepanations. Of course, trepanation and osteomyelitis can cooccur in a single skull. Infection following a skull fracture or an open scalp wound might be the motivation for trepanning, or the infection might be a complication of the surgery itself. There are many examples of trepanations surrounded by areas of 
inflammation, and it is not always clear which came first: the infection or the trepanation. However, bone infection alone can result in cranial defects, so this must be considered in interpreting cases where there is no clear evidence of surgical intervention.

Inflammation of the outer table of the cranium can result from scalp infections or trauma, and if healed, might be difficult to distinguish from an incomplete trepanation by the scraping method. While rare, documented historic cases of survival following traumatic scalp avulsion are known, and possible cases of survival following scalping have been found in prehistoric material as well (Ortner 2003: 165-167; Toyne 2011). Thus, scalp infection and scalp removal must be considered as diagnostic options in cases of healed, non-perforating lesions of the outer table, particularly if they involve large portions of the frontal and parietal bones.

\subsection{Neoplasm}

Metastatic carcinoma and multiple myeloma can produce destructive lesions in the skull vault (Figure 7). These are primarily lytic (destructive) lesions produced by rapidly growing tumor cells that have metastasized from other parts of the body (metastatic carcinoma) or proliferate within the bone marrow (multiple myeloma). These defects show characteristic features, including ragged, "punched out" margins with little or no new bone formation (Ortner 2003). Because they are the result of malignant tumors, healing is not expected in these cases, making it unlikely that these defects would be misdiagnosed as trepanations.

\subsection{Trauma}

Healed depressed fractures of the skull are frequently misdiagnosed as trepanations (Figure 8). This is often due to the mistaken belief (noted above) that trepanation defects heal by closing up the opening with new bone. In fact this rarely occurs. In comminuted fractures, where the cranial bone is broken into multiple fragments, isolated pieces of bone will lose their blood supply, die and be resorbed or sloughed off from the wound, or may be intentionally removed when a wound is cleaned. If the individual survives, defects of variable size and form will mark marking where bone fragments were lost. In cases of extensive healing, it can be difficult to tell if any intervention was done to treat the fracture.

Penetrating wounds to the skull also have been misdiagnosed as trepanations. If the wounds show no healing, their size and shape may allow matching them to particular weapons, such as spear points or star-headed maces, and to rule out the defect as a trepanation (Tyson and Alcauskas 1980 p. 9, Fig. E). If healed, it is more difficult to distinguish a penetrating wound from a small trepanation, although healed penetrating wounds are rare, due to their risk of infection and brain injury.

\subsubsection{Skull Defects Made by Edged Weapons}

In Europe and other parts of the Old World, sword and axe wounds are common during certain time periods (Campillo 2011), and some of these have been 
mistaken for trepanations (Bennike 2003). Unhealed sword injuries should be distinguishable from trepanations by the form of their cut marks (Figure 9).

\subsection{Suprainion Lesions}

Lesions on the occipital bone in the area above the anatomical landmark of Inion (the external occipital protuberance) were first suggested by Peruvian neurosurgeon Fernando Cabieses to be evidence of an unusual form of prophylactic trepanation performed on infants. Pathologist Pedro Weiss subsequently examined the question by studying collections of crania from the central coast of Peru, where these lesions are relatively common. Suprainion lesions are shallow depressions on the squamous portion of the occipital bone showing thinning and occasional perforation of the bone (Figure 10). Cabieses and Weiss hypothesized that these were scars from intentional scraping of the occipital bone, and classified them as trepanations. This interpretation is considered problematic by other scholars who have studied similar lesions in Peruvian, Mexican and North American Indian crania. T. Dale Stewart published the first comprehensive study of these lesions (Stewart 1975b), noting that they were found in various cultures (including those of the central coast of Peru) where infants' heads were strapped to cradleboards or other head-shaping devices. Stewart concluded that the lesions were the result of ischemia or inflammation caused by localized pressure on the back of the skull, not the result of trepanation by scraping. In support of his argument he noted that no example was known from Peru or from anywhere else of an unhealed suprainion lesion that showed tool marks, and argued that unhealed cases would be expected, since a $100 \%$ survival rate for such procedures would be surprising, especially in infants. Unhealed suprainion lesions have been found in infants, but these are typically porous areas that do not show any evidence of cut marks or scraping (Figure 11). Stewart also noted, correctly, that no other form of trepanation was practiced on the central coast of Peru, making it difficult to imagine that a procedure like this would evolve and become common in an area with no prior experience with trepanation.

A more recent study of a Pueblo Indian skeletal sample from southwestern New Mexico by Diane Holliday found a high frequency of suprainion lesions (both active and healed) associated with cradleboarding (Holliday 1993). Like Stewart, Holliday found no evidence of cutting or scrape marks that would identify them as trepanations. While most suprainion lesions heal and remain as simple depressions in adults, a recent case report concludes that, although rare, serious infection and death were potential risks of cradleboarding (Mendonça de Souza, Reinhard, and Lessa 2008).

Discussion and debate continues on suprainion trepanation, despite evidence of a relationship between cranial deformation and suprainion lesions and a lack of unhealed suprainion lesions showing cut or scrape marks. This is particularly true in the case of the ancient Maya, where suprainion lesions have been reported, but where there is a lack of convincing evidence of any other forms of trepanation (Velasco-Suarez et al. 1992; Tiesler 2012: 45-47). From the author's examination of many hundreds of deformed crania from the central and north coast of Peru, no 
evidence has been found to support the hypothesis that suprainion lesions are the result of trepanation.

\subsection{Postmortem Taphonomic Damage}

Postmortem damage to crania can be produced by a variety of mechanisms, including breakage or erosion, surface weathering of exposed bone, and chewing by carnivores and rodents. Postmortem breakage or erosion of bone is normally fairly easy to recognize because of the absence of any evidence of bone reaction and by different coloration of broken edges indicating recent breakage. However, sun bleaching and abrasion by windblown sand can erode away exposed bones, occasionally mimicking trepanations (Figure 12).

Carnivore gnawing is relatively easy to recognize by features such as puncture marks, deep grooves, and breakage of bone. Rodent gnawing is more subtle, and it has resulted in misidentifications of cranial defects as "trepanations" (Fig . 13). In cases such as these, careful examination of the margins of a defect will reveal the characteristic paired chisel marks of the rodent's central incisors, which leave small furrows along the margins of holes that are oriented perpendicular, rather than parallel to the edge of the hole; a pattern unlike that done by a human hand cutting or scraping bone.

\section{Differential Diagnosis: Examples from Archaeological Material}

Examples are presented here of two crania showing trepanations by the scraping method. They come the central highlands of Peru, where trepanation was widely practiced in the late prehistoric period. More than four hundred trepanned crania have been recovered from archaeological sites in this region, so there is no question that cranial surgery was practiced here (Verano 2016). The first case (Figure 13) is straightforward, as it is an example of trepanation with no evidence of healing. The cranium shows extensive scraping of the frontal bone through the outer table and diploe, and a number of small defects through the inner table. Scrape marks and portions of exposed diploe are clearly visible, and there is no evidence of bone reaction around the margins of the scraped area, indicating death during or shortly after the procedure. The second case (Figure 14) is an example of a healed cranial defect that is most likely a trepanation by scraping. It shows a roughly circular smooth-edged hole surrounded by a larger area of remodeled bone. Healing has obliterated any cut or scrape marks. A possible differential diagnosis would be a healed depressed skull fracture with loss of broken fragments in the center of the wound, but there are no radial or concentric fractures as might be expected in the case of a severe blow to the head. This location on the frontal bone is not a site where one might expect ossification or developmental defects to occur, so these would be unlikely diagnoses as well. What is unequivocal is that this individual survived for an extended period of time with a healed defect in the skull.

\section{Conclusions}

In the absence of medical history or firm archaeological context and dating, diagnosing defects in skulls can be challenging. This is particularly true in the case of healed defects of the cranium, since bone remodeling normally erases the tool 
marks that identify surgical intervention. Unhealed holes in skulls, even if clearly made by human hands, also raise the issue of whether a trepanation was done in a living patient or as a postmortem experiment or ritual, such as the removal of discs of bone (Piggot 1940; Prunières 1874). Particularly challenging are isolated cases of crania found in a region where trepanation has not otherwise been identified. In discussing such cases, Donald Ortner made the following observation:

"In such situations... the demonstration of unambiguous trephination in the same geographical area would certainly be significant in interpreting the equivocal cases." (Ortner 2003:171)

Even in regions such as Andean South America, where skull surgery was common, differential diagnosis is important for confidently identifying trepanations and for distinguishing them from cranial defects resulting from developmental disorders, disease, trauma, and taphonomic processes.

Acknowledgments

Funding for travel to museums and archaeological sites was made possible by Fulbright Lectureships in Peru $(1989,1996)$ and travel grants from the Research Opportunities Fund of the National Museum of Natural History, Smithsonian Institution (1992) and the Roger Thayer Stone Center for Latin American Studies at Tulane University (2002).

\section{References Cited}

Alt KW, Jeunesse C, Buitrago-Tellez CH, Wachter R, Boes E, Pichler SL. 1997. Evidence for stone age cranial surgery. Nature 387:360.

Barbian, LT., and PS. Sledzik 2008. Healing Following Cranial Trauma. Journal of Forensic Sciences 53(2): 263-268.

Barnes E. 1994. Developmental defects of the axial skeleton in paleopathology. Niwot, Colo.: University Press of Colorado.

Barnes E. 2012. Atlas of developmental field anomalies of the human skeleton: a paleopathology perspective. Hoboken, N.J: John Wiley and Sons.

Bazarsad N. 2003. Four Cases of Trepanation from Mongolia, Showing Surgical Variation. In: Arnott R, Finger S, Smith, C.U.M., editors. Lisse, The Netherlands: Swets \& Zeitlinger. p 203-208.

Bennike P. 2003. Ancient Trepanations and Differential Diagnoses: A Re-evaluation of Skeletal Remains from Denmark. In: Arnott R, Finger S, Smith CUM, editors. Trepanation: History, Discovery, Theory. Lisse: Swets \& Zeitlinger. p 95-115. 
Campillo D. 2007. La trepanación prehistórica. Barcelona: Edicions Bellaterra.

Campillo D. 2011. Paleopatología de las lesiones violentas, anteriores al descubrimiento de la pólvora. Medicina e Historia:1-16.

Cederlund C-G, Andrén L, Olivecrona H. 1982. Progressive bilateral thinning of the parietal bones. Skeletal Radiology 8:29-33.

Crubézy É, Bruzek J, Guilaine J, Cunha E, Rougé D, Jelinek J. 2001. The antiquity of cranial surgery in Europe and in the Mediterranean basin. Comptes Rendus de l'Académie des Sciences - Series IIA - Earth and Planetary Science 332:417-423.

Ferembach D. 1962. La Necropole Epipaleolithique de Taforalt(Maroc Oriental), Etude de Squelettes Humains. Rabat: Centre National de la Recherche Scientific.

Goldsmith WM. 1945. Trepanation and the "Catlin Mark." American Antiquity 10:348-353.

Han K, Cheng X. 2007. The Archaeological Evidence of Trepanation in Early China. IndoPacific Prehistory Association Bulletin 27:22-27.

Holliday DY. 1993. Occipital lesions: A possible cost of cradleboards. American Journal of Physical Anthropology 90:283-290.

Kaufman MH, Witaker D, McTavish J. 1997. Differential Diagnosis of Holes in the Calvarium: Application of Modern Clinical Data to Palaeopathology. Journal of Archaeological Science 24:193-218.

Klaus, HD, and EE Byrnes. 2013. Cranial Lesions and Maxillofacial Asymmetry in an Archaeological Skeleton from Peru. A Paleopathological Case of Possible TraumaInduced Epidermal Inclusion Cysts. Journal of Cranio-Maxillary Diseases 2: 46-53.

Lastres, JB, and F Cabieses 1960. La trepanación del cráneo en el antiguo Perú. Universidad Nacional Mayor de San Marcos, Lima.

Lillie MC. 1998. Cranial surgery dates back to Mesolithic. Nature 391:854.

Lisowski FP. 1967. Prehistoric and early historic trepanation. In: Brothwell DR, Sandison AT, editors. Diseases in Antiquity. Springfield, Illinois: Charles C. Thomas. p 651-672.

Lv X, Li, Zhenguang, Li, Youxiang. 2013. Prehistoric Skull Trepanation in China. World Neurosurgery 80:897-899.

Mendonça de Souza SMF, Reinhard KJ, and A. Lessa 2008. Cranial deformation as the cause of death for a child from the Chillon River Valley, Peru. Chungara, Revista de Antropología Chilena 40:41-53. 
Merbs CF. 1989. Trauma. In: Yasar Iscan M, Kennedy KAR, editors. Reconstruction of Life from the Skeleton. New York: Alan R. Liss. p 161-189.

Murphy EM. 2003. Trepanations and perforated crania from Iron Age south Siberia: an exercise in differential diagnosis. In: Arnott R, Finger S, Smith, C.U.M., editors. Trepanation: History, Discovery, Theory. Lisse, The Netherlands: Swets \& Zeitlinger. p 209-221.

Nerlich A, Peschel O, Zink A, Rösing FW. 2003. The Pathology of Trepanation: Differential Diagnosis, Healing and Dry Bone Appearance in Modern Cases. In: Arnott R, Finger S, Smith CUM, editors. Trepanation: History, Discovery, Theory. Lisse, The Netherlands: Swets \& Zeitlinger. p 43-51.

Ortner DJ. 2003. Identification of pathological conditions in human skeletal remains. 2nd ed. Amsterdam; Boston: Academic Press.

Piggott, S. 1940. A trepanned skull of the Beaker period from Dorset and the practice of trepanning in prehistoric Europe. Proceedings of the Prehistoric Society 6:112-132.

Prunières, B. 1874. Sur les crânes perforés et les rondelles crâniennes de l'époque néolithique. Association Française pour l'Avancement des Sciences Compte Rendu (Paris) 1874 3: 597-635.

Sauer NJ, Dunlap SS. 1985. The Asymmetrical Remodelling of Two Neurosurgical Burr Holes: A Case Study. Journal of Forensic Sciences 30:953-957.

Stewart, TD. 1956. Significance of osteitis in ancient Peruvian trephining. Bulletin of the History of Medicine 30: 293-320.

Stewart, TD. 1975a. Cranial dysraphism mistaken for trephination. American Journal of Physical Anthropology 42(3): 435-437.

Stewart TD. 1975b. Are supra-inion depressions evidence of prophylactic trephination? Bulletin of the History of Medicine 50:414-434.

Tiesler V. 2012. Transformarse en Maya: El modelado cefálico entre los mayas prehispánicos y coloniales. 1a. edition. Mexico: Universidad Nacional Autónoma de Mexico, Instututo de Investigaciones Antropológicas, Universidad de Yucatán.

Toyne JM. 2011. Possible Cases of Scalping from Prehispanic Highland Peru. International Journal of Osteoarchaeology. 21:2:227-242.

Tyson RA and Alcauskas ESD (eds.) 1980. Catalogue of the Hrdlicka paleopathology collection. San Diego, Calif.: San Diego Museum of Man. 
Velasco-Suarez M, Martinez JB, Oliveros RG, Weinstein PR. 1992. Archaeological origins of cranial surgery: trephination in Mexico. Neurosurgery 31:313-319.

Verano, JW. 2016. Holes in the Head, The Art and Archaeology of Trepanation in Ancient Peru. Washington, D.C.: Dumbarton Oaks Research Library and Collections Studies in Pre-Columbian Art and Archaeology Number 38.

Verano JW, Andrushko VA. 2008. Cranioplasty in Ancient Peru: A critical review of the evidence, and a unique case from the Cuzco Area. International Journal of Osteoarchaeology 18:1-11.

Wilms G, Van Roost W, Van Russelt J, Smits J. 1983. Biparietal thinning: correlation with CT findings. Radiologe 23:385-6. 
Figure Captions

Figure 1. Illustration of trepanation methods: (1) scraping, (2) circular grooving, (3) drilling and cutting, and (4) linear cutting with angular intersections. From Lisowski 1967: Figure 1, Courtesy of Charles C. Thomas Publisher, Ltd., Springfield, Illinois.

Figure 2. Trepanation of the right parietal with short term healing. Large arrows in center mark osteoclastic activity at the margins of the opening, and (lower arrow) a portion of necrotic bone that preserves cut/scrape marks from the trepanation. The smaller arrows around the periphery mark the outer margins of necrotic bone (line of demarcation). Central highland Peru. Courtesy of Peru's National Museum of Anthropology, Archaeology and History, photo by author.

Figure 3a,b. Lateral and superior views of the skull of an infant diagnosed with hydrocephalus, showing great expansion of the cranial vault with forward projection of the frontal bones and an enlarged anterior fontanelle. University of Nebraska, Lincoln, Anthropology Department, with permission of Karl Reinhard. Anatomical specimen, photo by author.

Figure 4a,b. Cranium with Meningocoele, superior (a) and oblique view from the left side. Chicama Valley, Peru, NMNH 264629. Photo courtesy of David Hunt, Department of Anthropology, National Museum of Natural History, Smithsonian Institution.

Figure 5. Parietal fenestrae. The cranium on the left shows the typical form of oval defects. The cranium on the right shows the slit-like variant. NMNH 276981, Ponce Mound, Santa Clara County, California (left) and NMNH 276982, near Palo Alto, California (right). Photograph courtesy of David Hunt, Department of Anthropology, National Museum of Natural History, Smithsonian Institution.

Figure $6 a$,b. Left and right oblique lateral views of an old adult cranium with biparietal thinning. The paper-thin bone can be seen in areas of breakage, particularly on the left side, and the parietal foramina rise above the level of surrounding bone. Modern anatomical specimen, Department of Anthropology, Tulane University, photos by the author.

Figure 7. Large erosive lesion on frontal bone. Possible metastatic carcinoma. Courtesy of the National Museum of Anthropology, Archaeology, and History of Peru, AF: 7075, photo by the author.

Figure 8. Healed depressed fracture on the frontal bone. Identified in a museum catalog as a trepanation, it is more likely a depressed fracture. Hacienda Ocucaje, Ica Valley, South Coast of Peru. Ica Regional Museum 00292-12, MRI-DB-34. 
Figure 9. Cranium with a saber wound on the frontal bone. The large arrow indicates the direction of a glancing blow that left several chatter marks (small arrows), where the blade cut into bone and then bounced off, and continued to cut through bone, leveraging out a large fragment. The wound shows no sign of healing. National Museum of Natural History, Smithsonian Institution, NMNH 209434, photo by the author.

Figure 10. Healed suprainion lesion on an adult skull from the central coast of Peru. Arrows indicate the approximate margins of the lesion. Weiss collection, courtesy of the Archaeology Museum of the National University of San Marcos. Photo by the author.

Figure 11. A suprainion lesion on the occipital bone of an infant less than six months of age that was active at the time of death. It shows a focal area of osteoclastic activity (bone destruction), surrounded by a larger, smooth-surfaced area of necrotic bone. El Brujo Lambayeque Period burial, Chicama Valley, Peru. L98-14. Photo by the author.

Figure 12. Cranium showing sun bleaching and sand erosion. Hacienda Ocucaje, Ica, Peru. Courtesy of the Ica Regional Museum, MRI-DB-4329, 00868-12. Photo by the author

Figure 13. Cranium catalogued as "trepanned", but which more likely represents postmortem breakage and rodent gnawing. The margins of a hole in the left parietal bone show extensive damage by rodent gnawing, visible as small furrows oriented perpendicular to the margin of the defect. From Hacienda Cabildo, Ica, Peru. Courtesy of the Ica Regional Museum, 00863-12, Photo by the author.

Figure 14. Unhealed trepanation by scraping, central highlands of Peru, NMNH 293643, courtesy of the National Museum of Natural History, Smithsonian Institution. Photo by the author.

Figure 15. Healed trepanation from central highlands of Peru. Hrdlička Collection, SDMM 264a. Courtesy of the San Diego Museum of Man. Photo by the author. 
Figure's

Figure 1

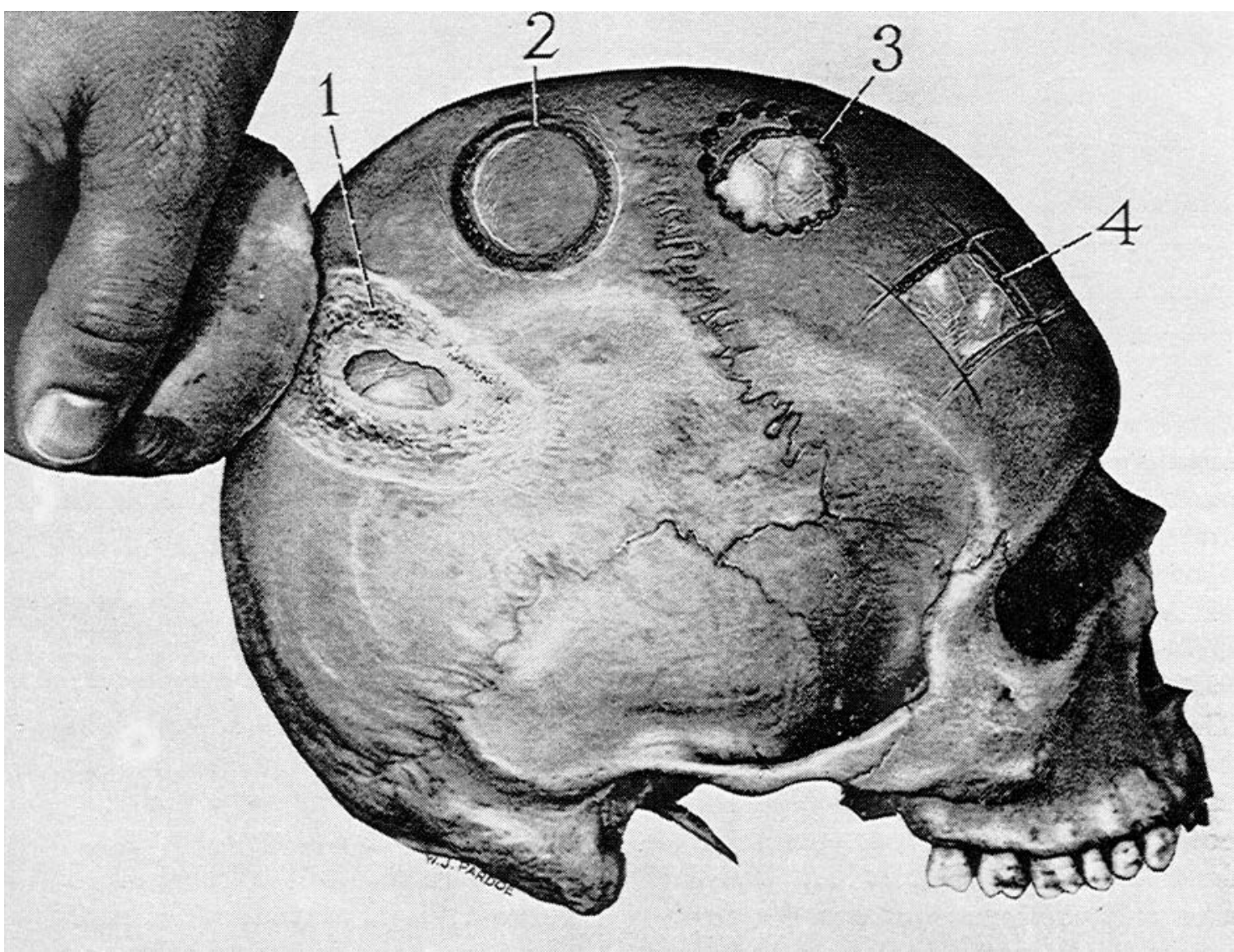


Figure 2

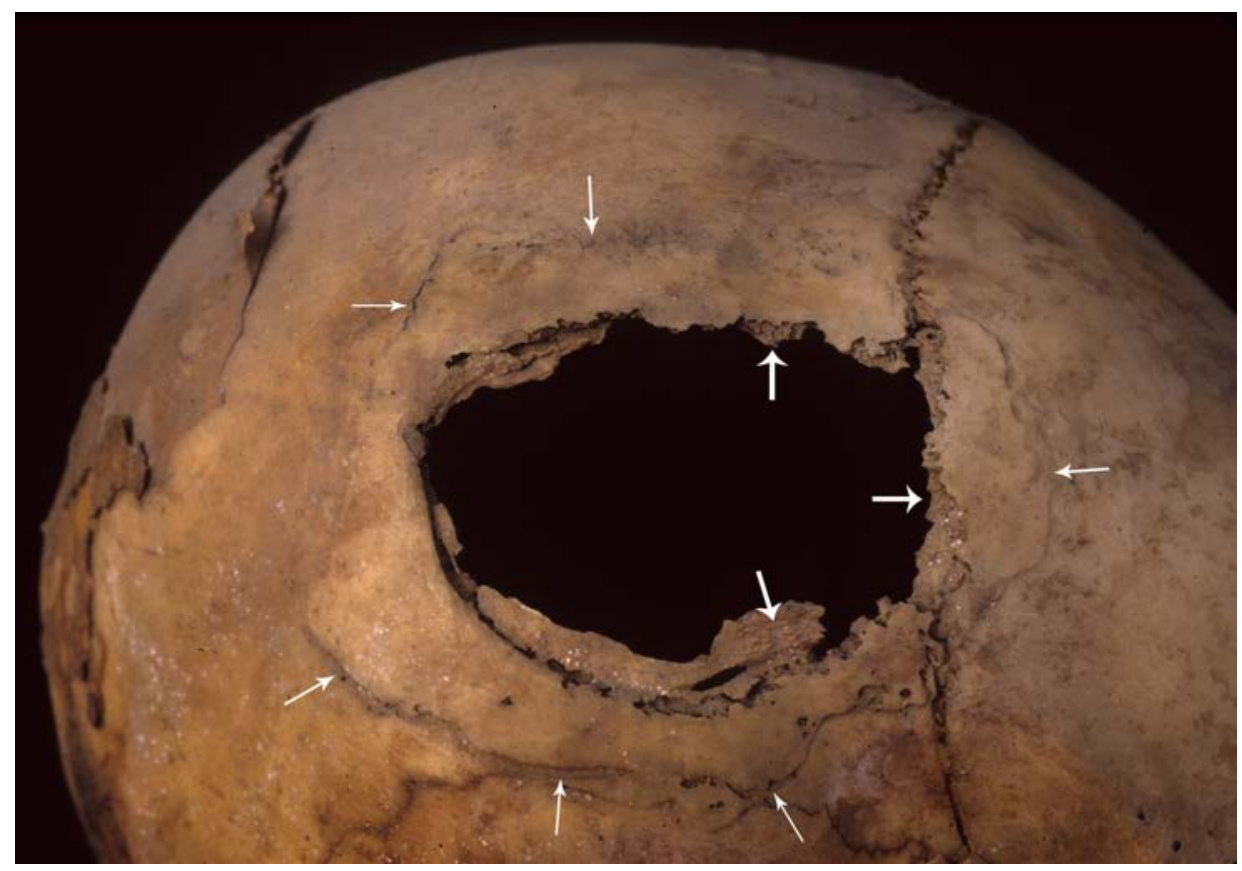


Figure $3 a$

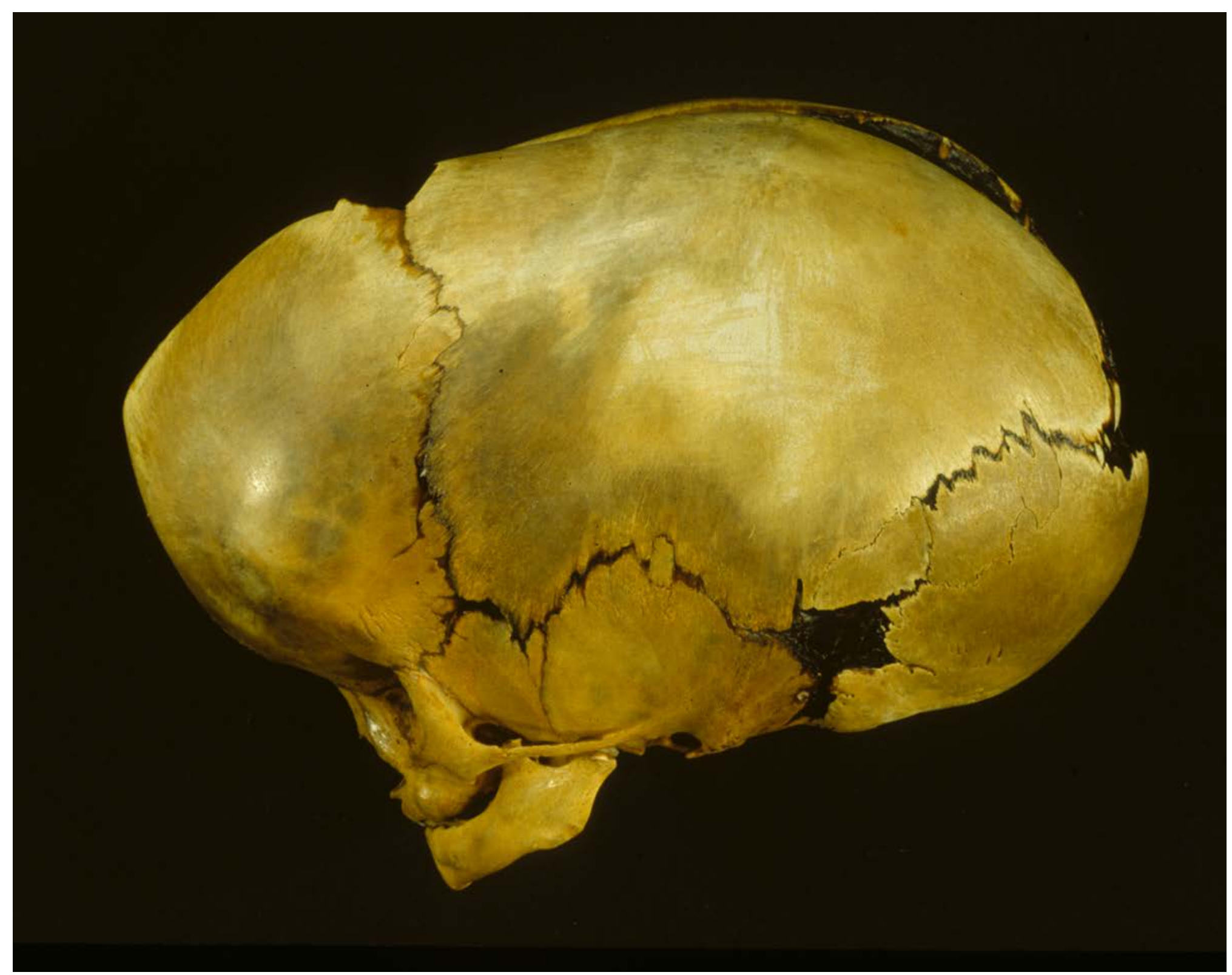


Figure 3b

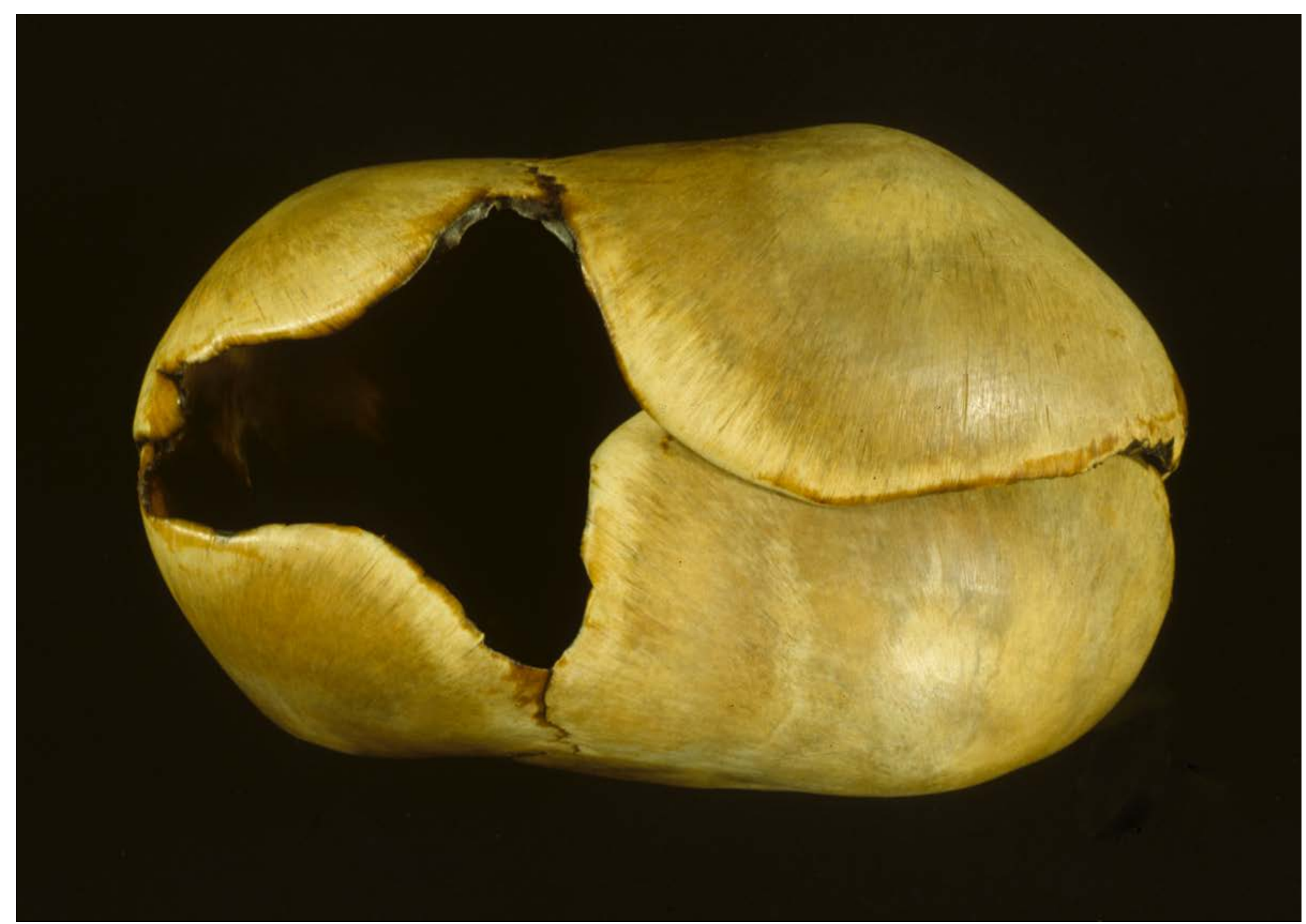


Figure $4 a$

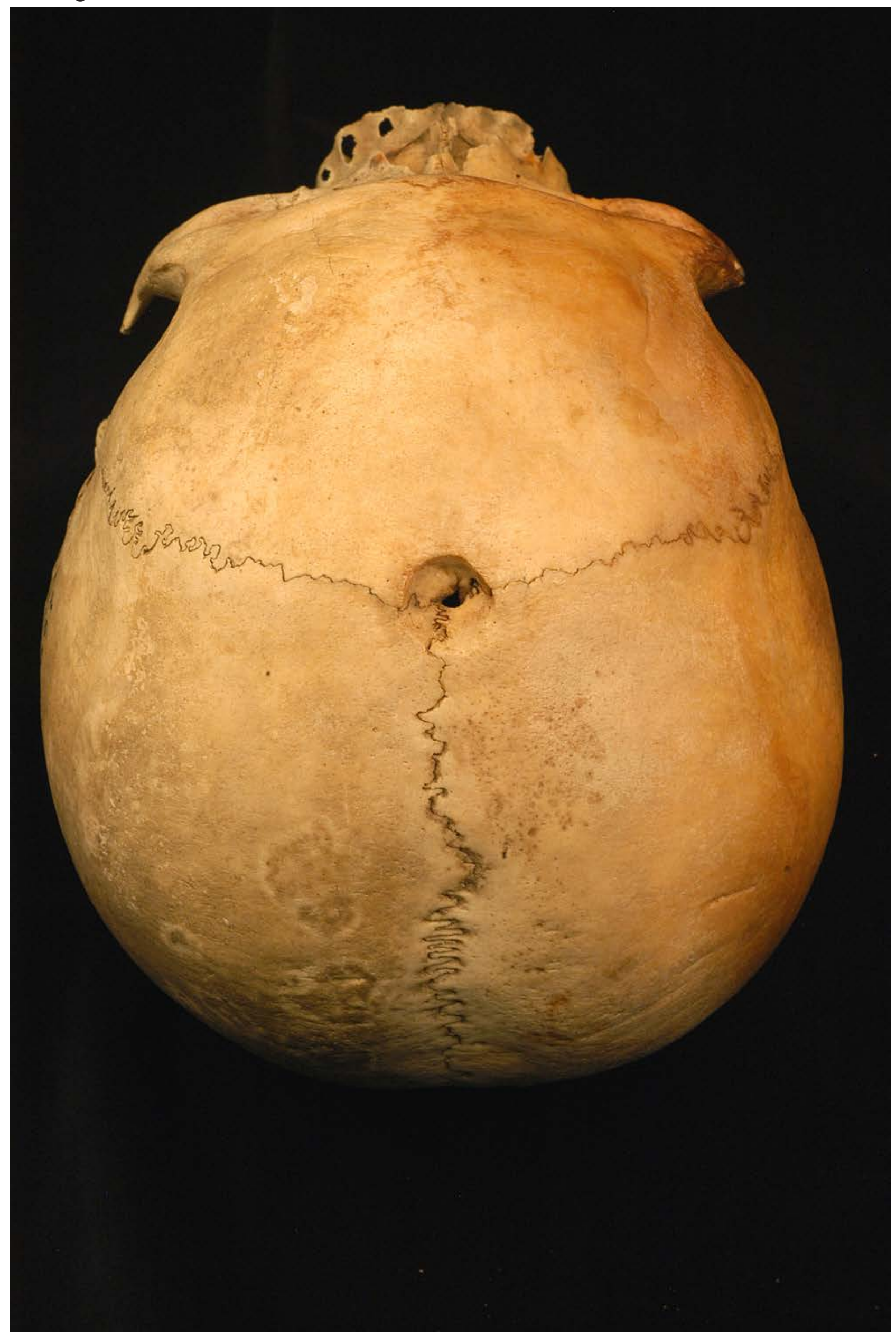


Figure 4b

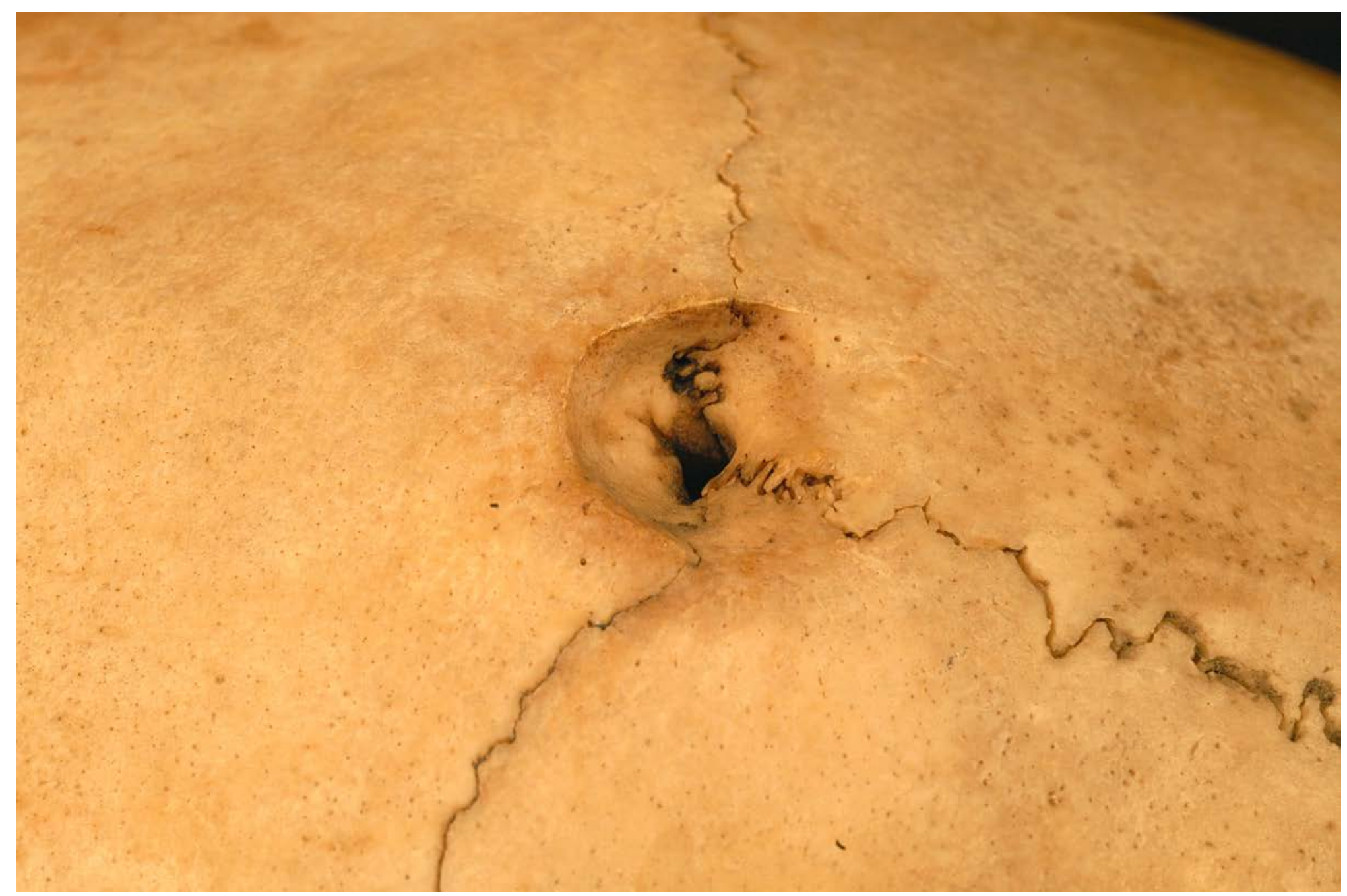


Figure 5

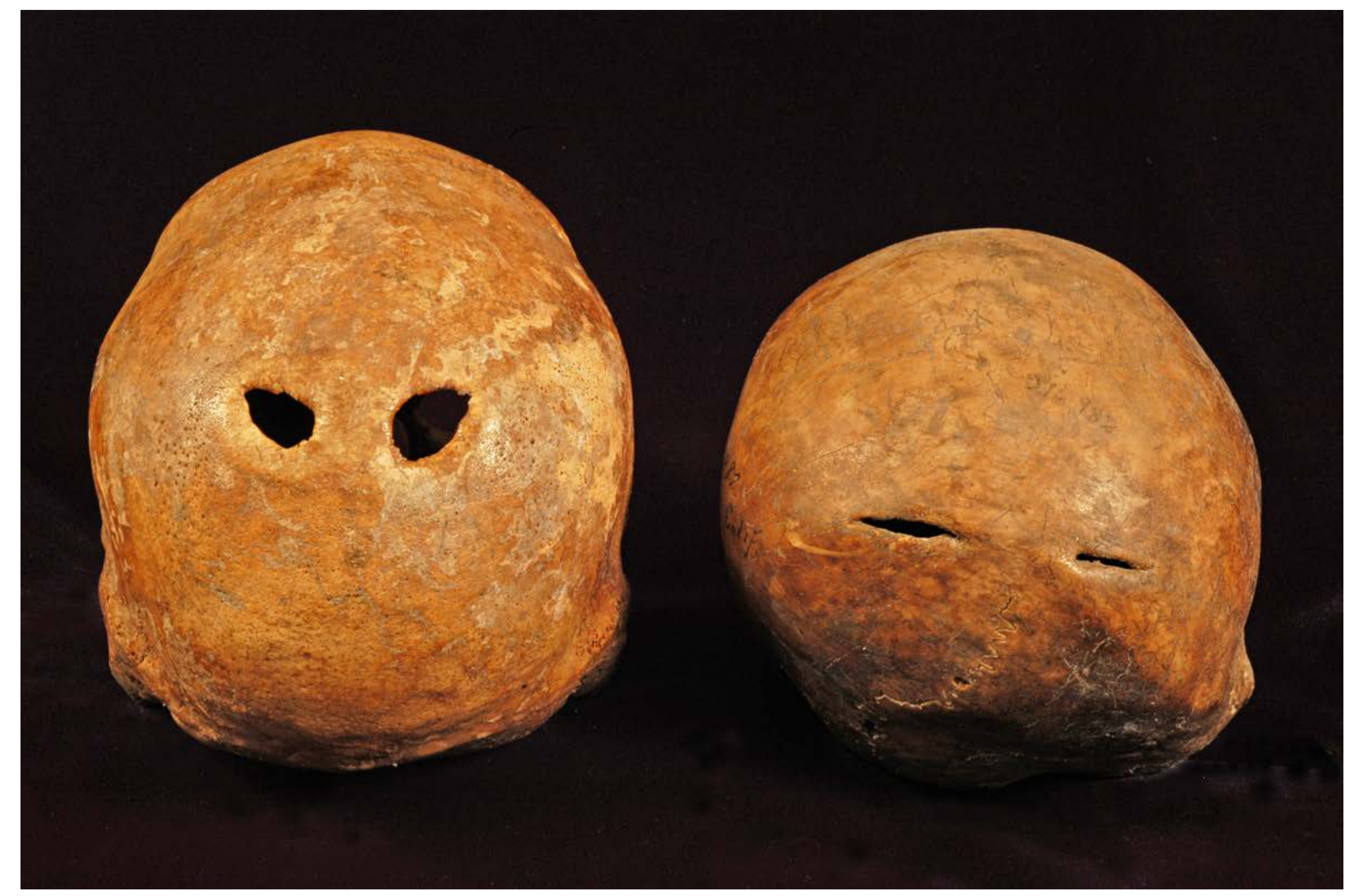


Figure 6b

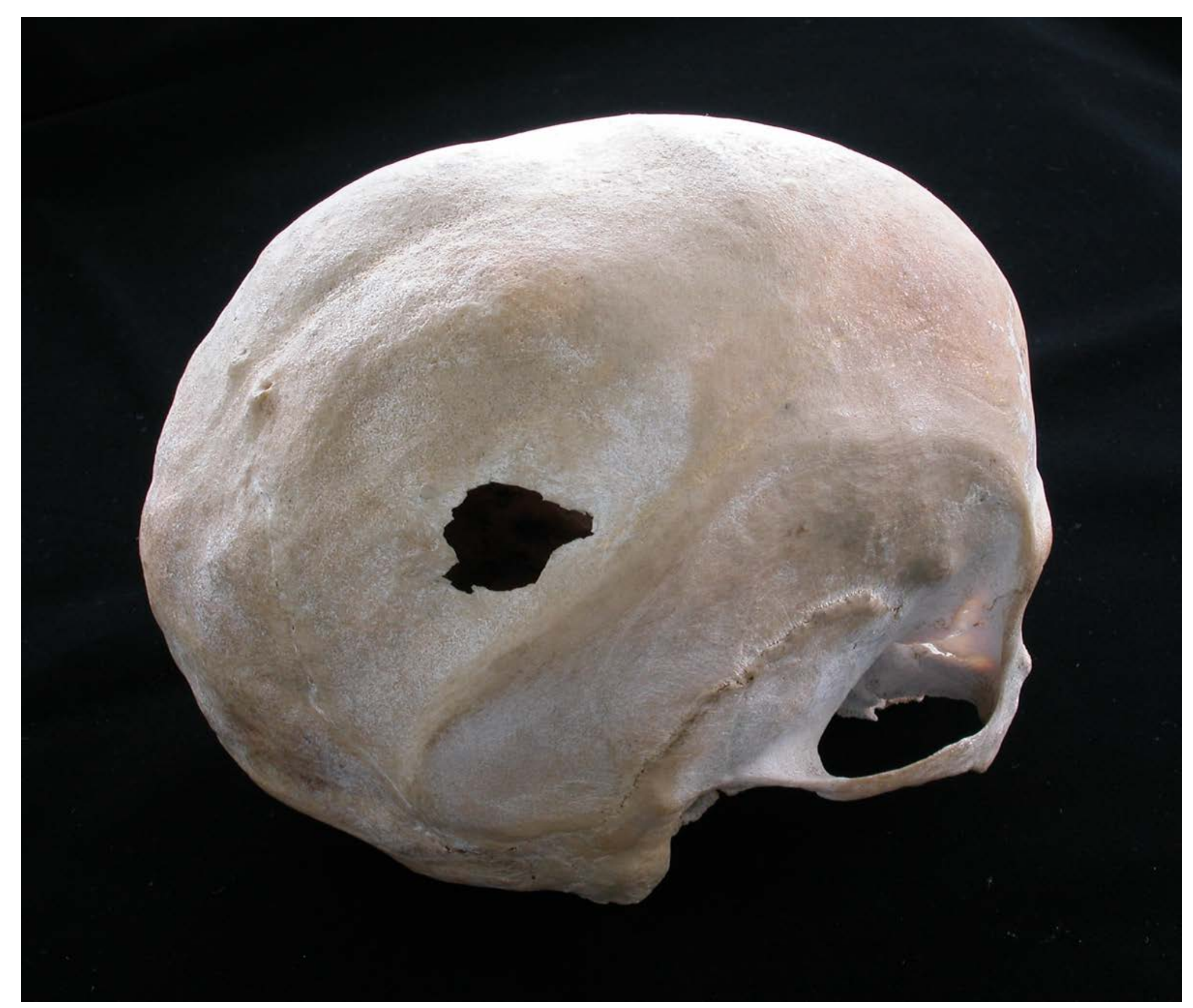


Figure 7

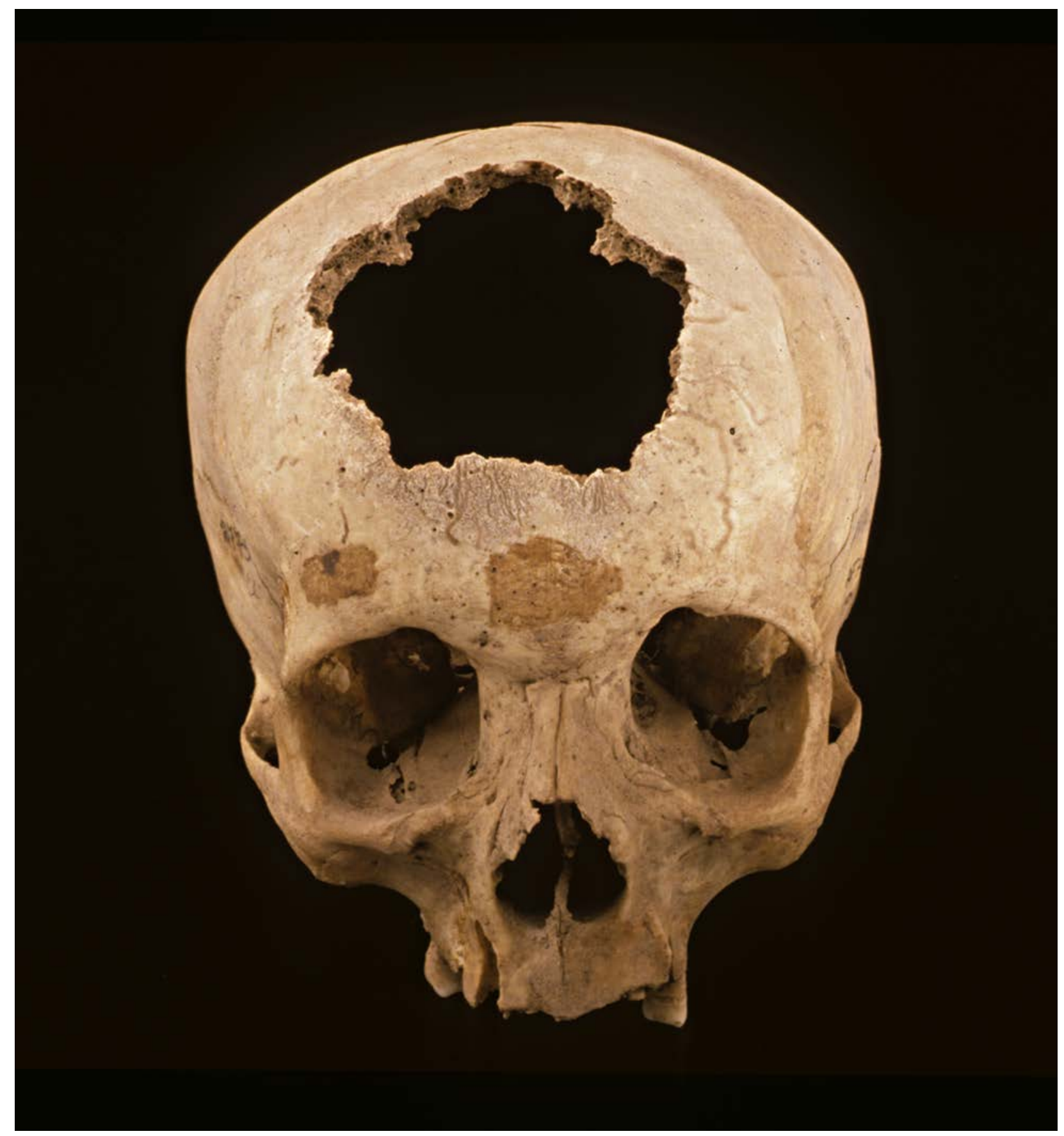


Figure 8

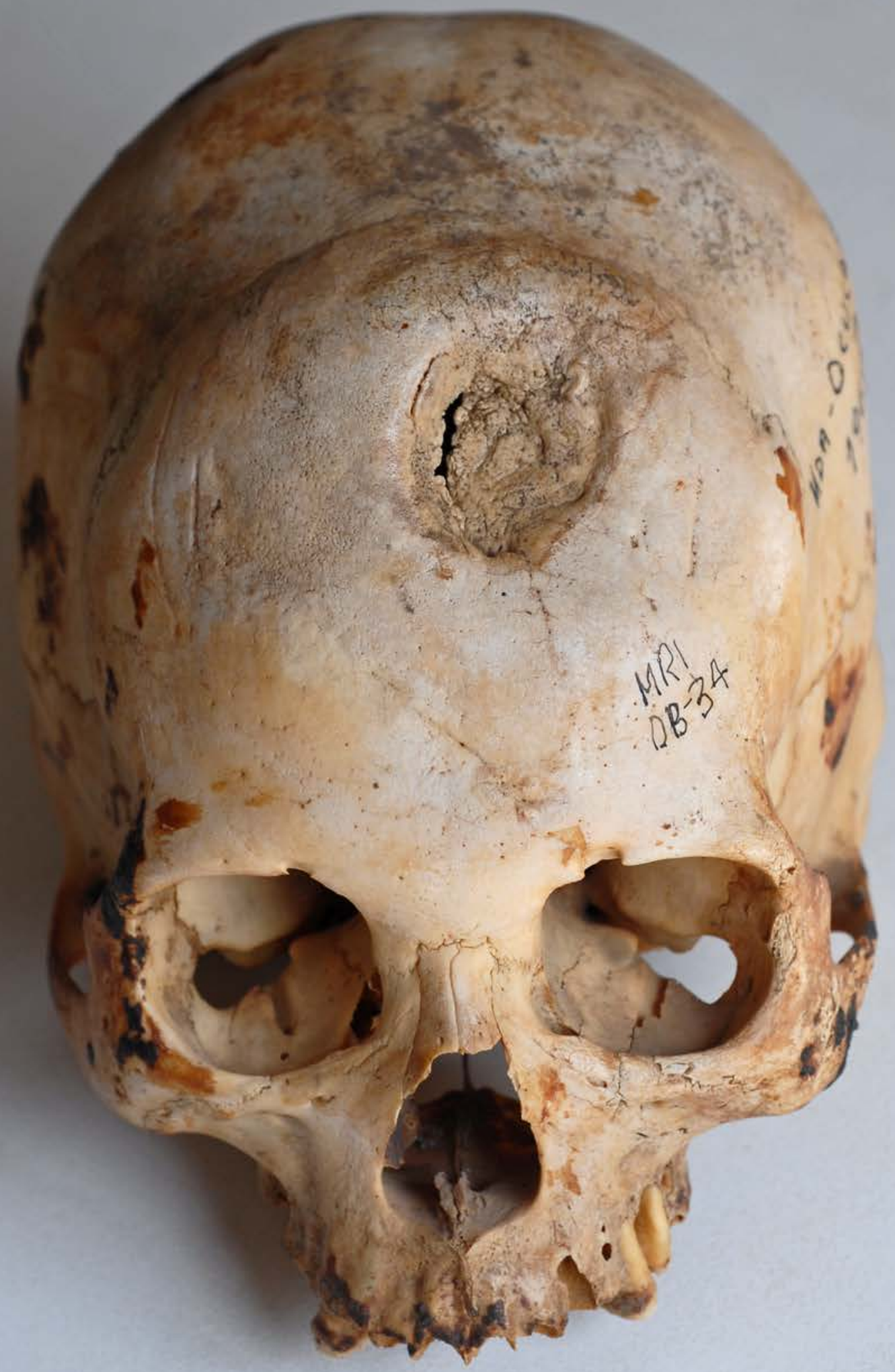


Figure 9

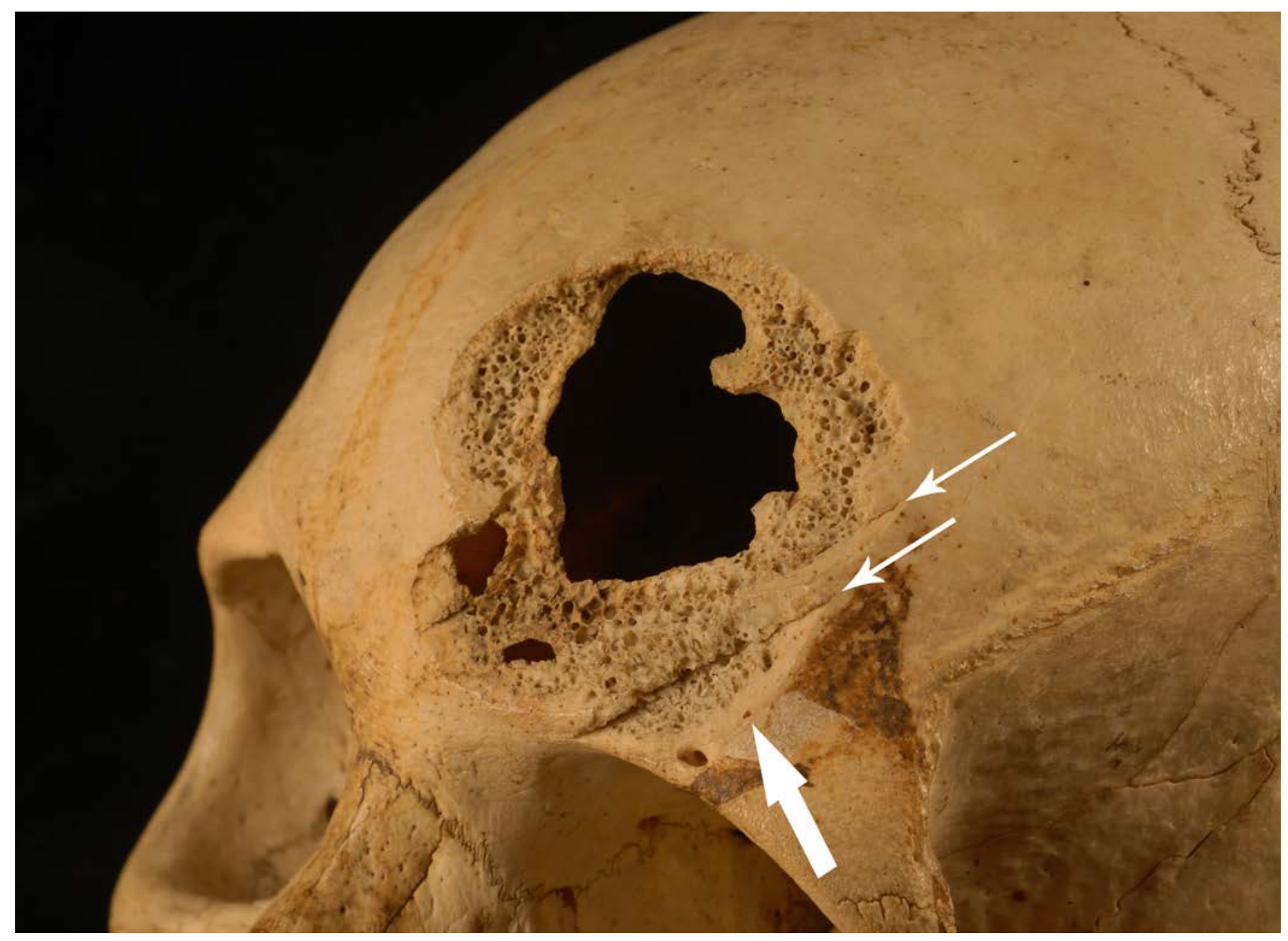


Figure 10

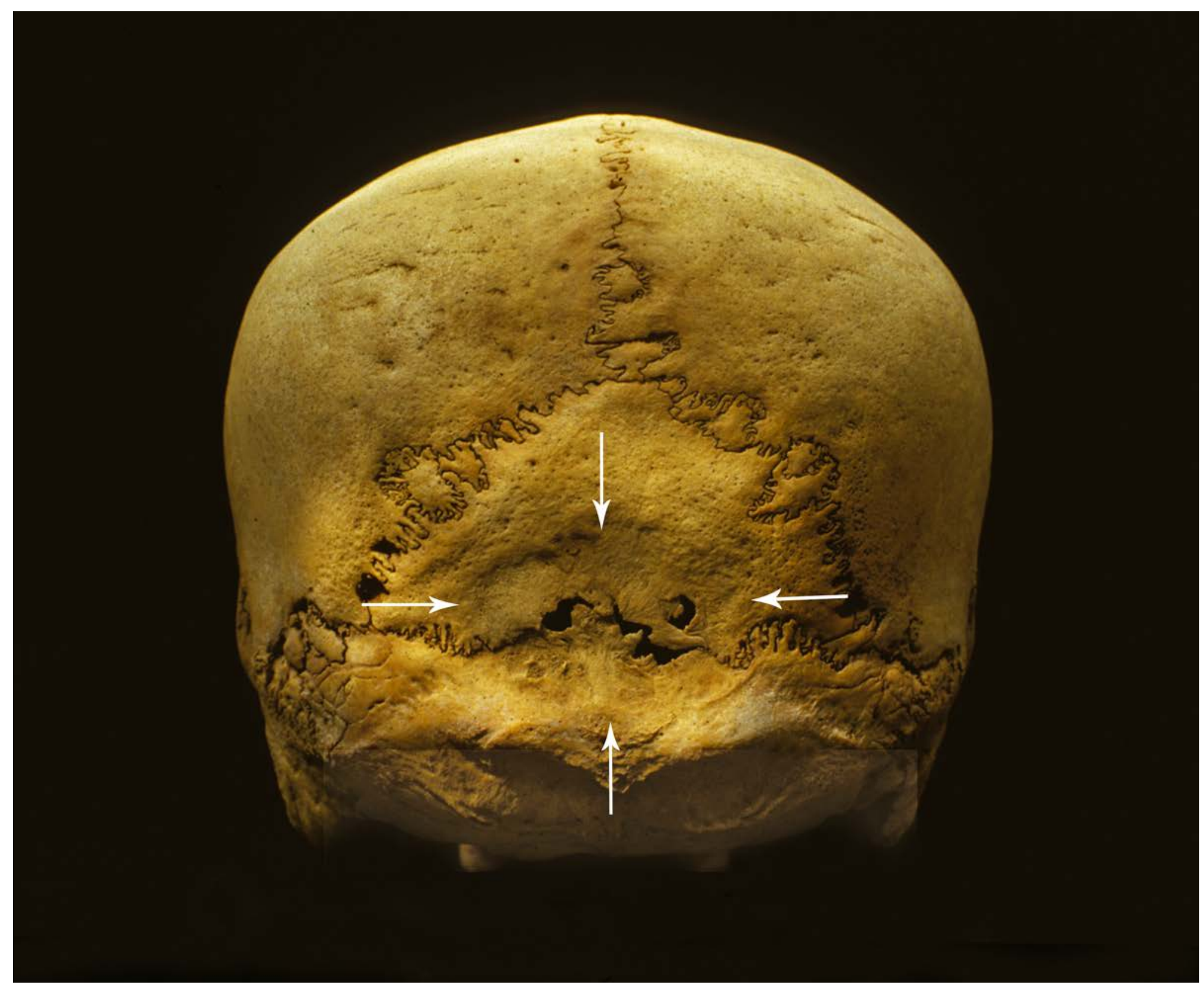


Figure 11

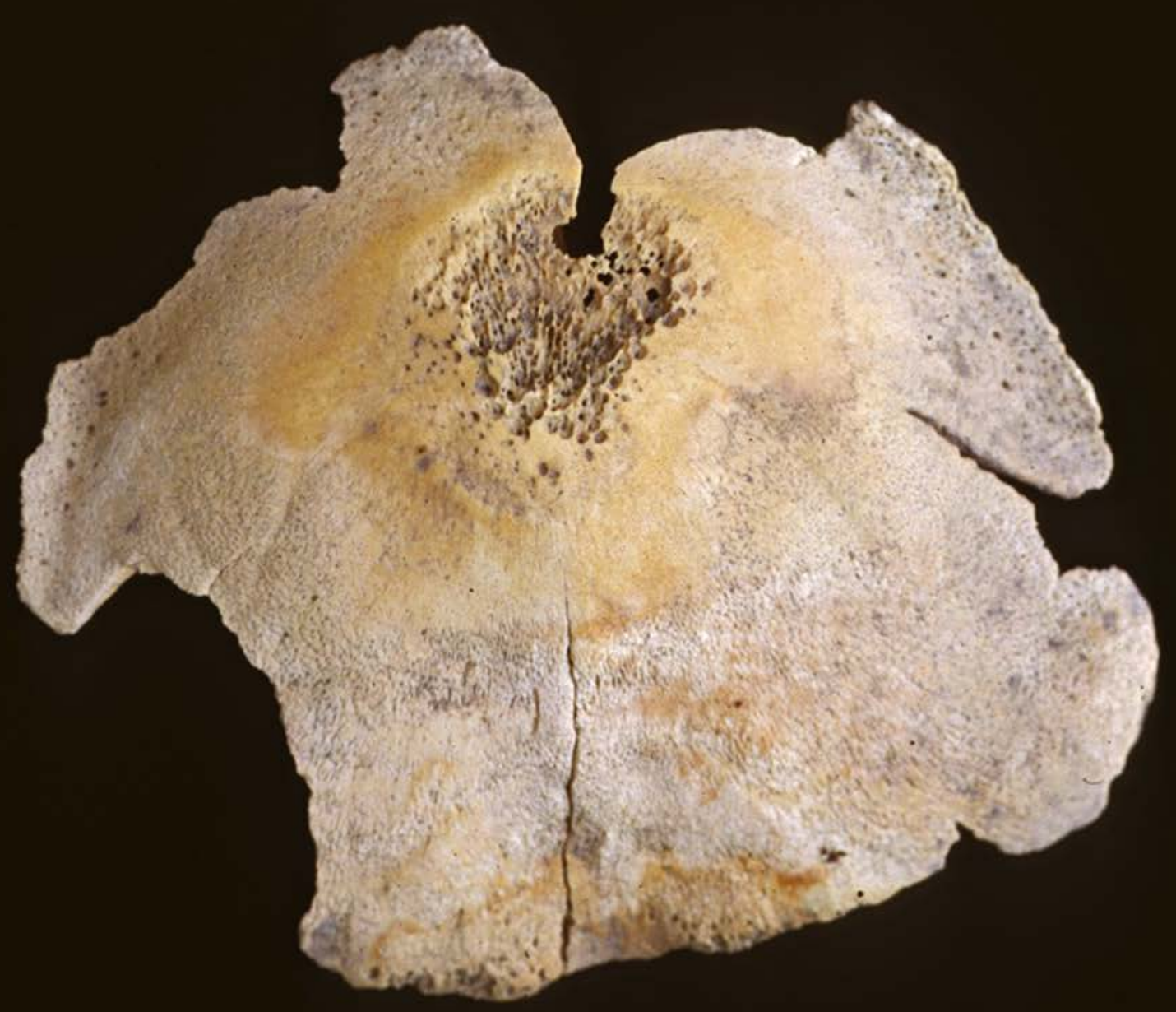


Figure 12

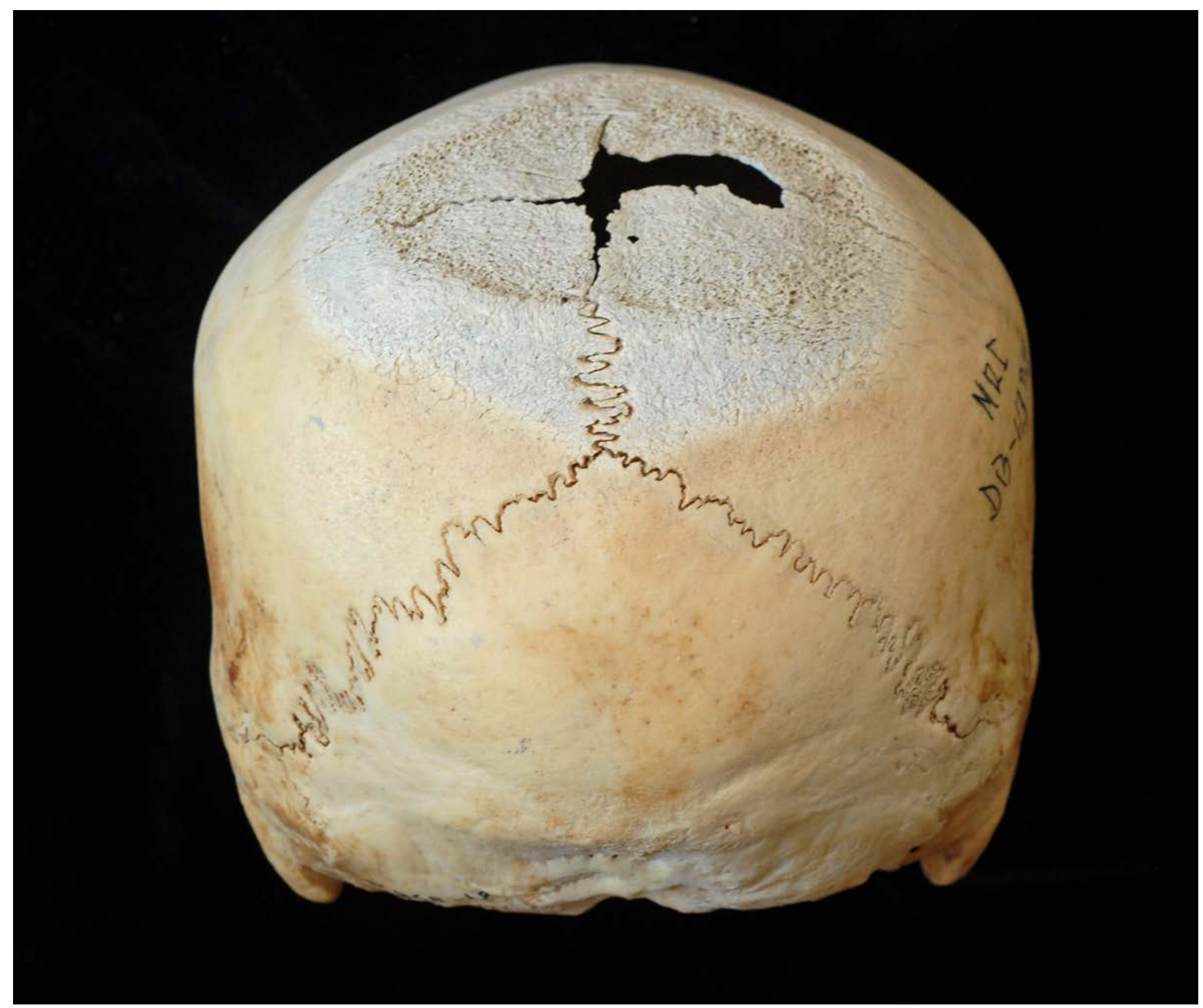


Figure 13

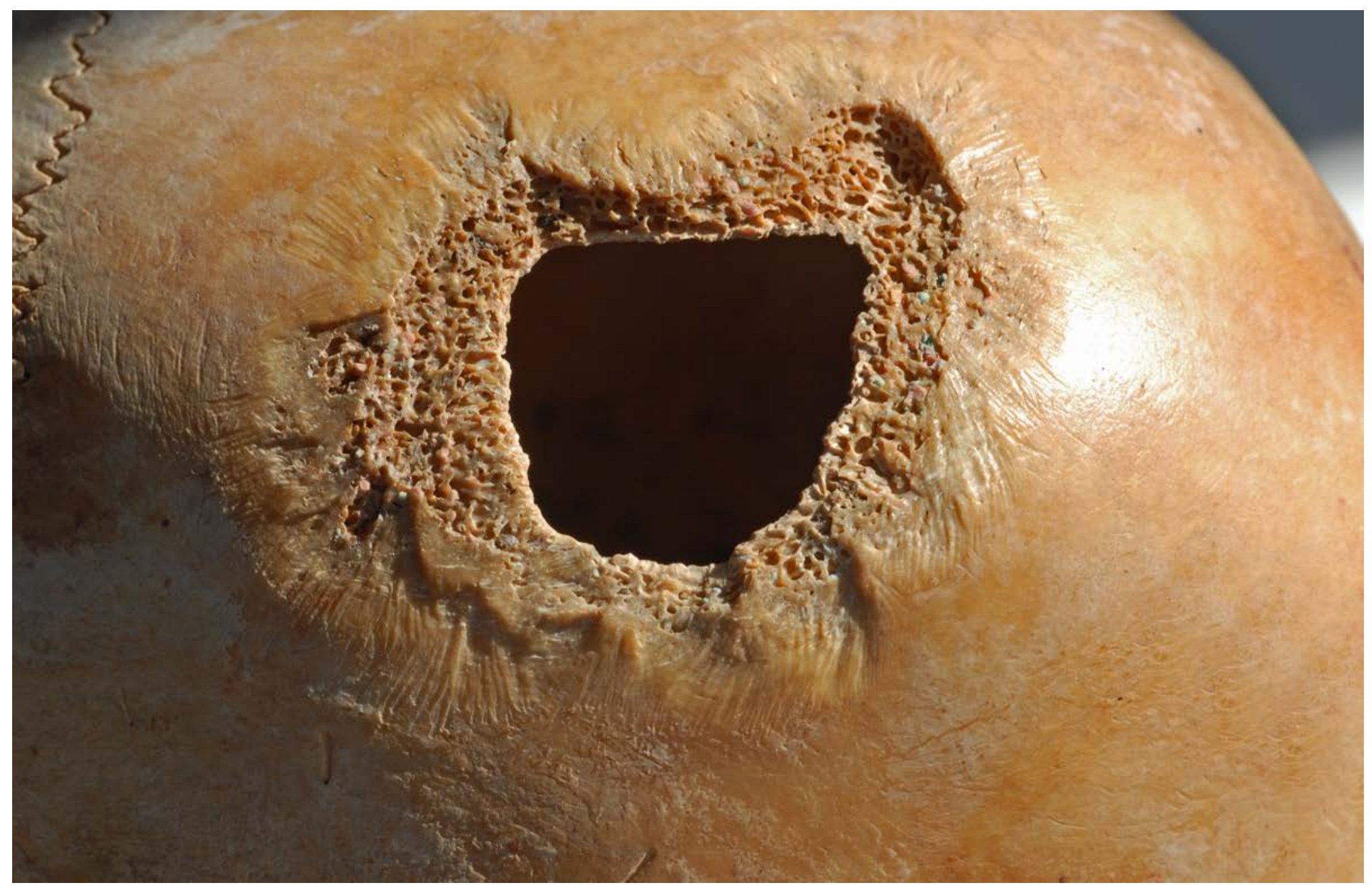


Figure 14

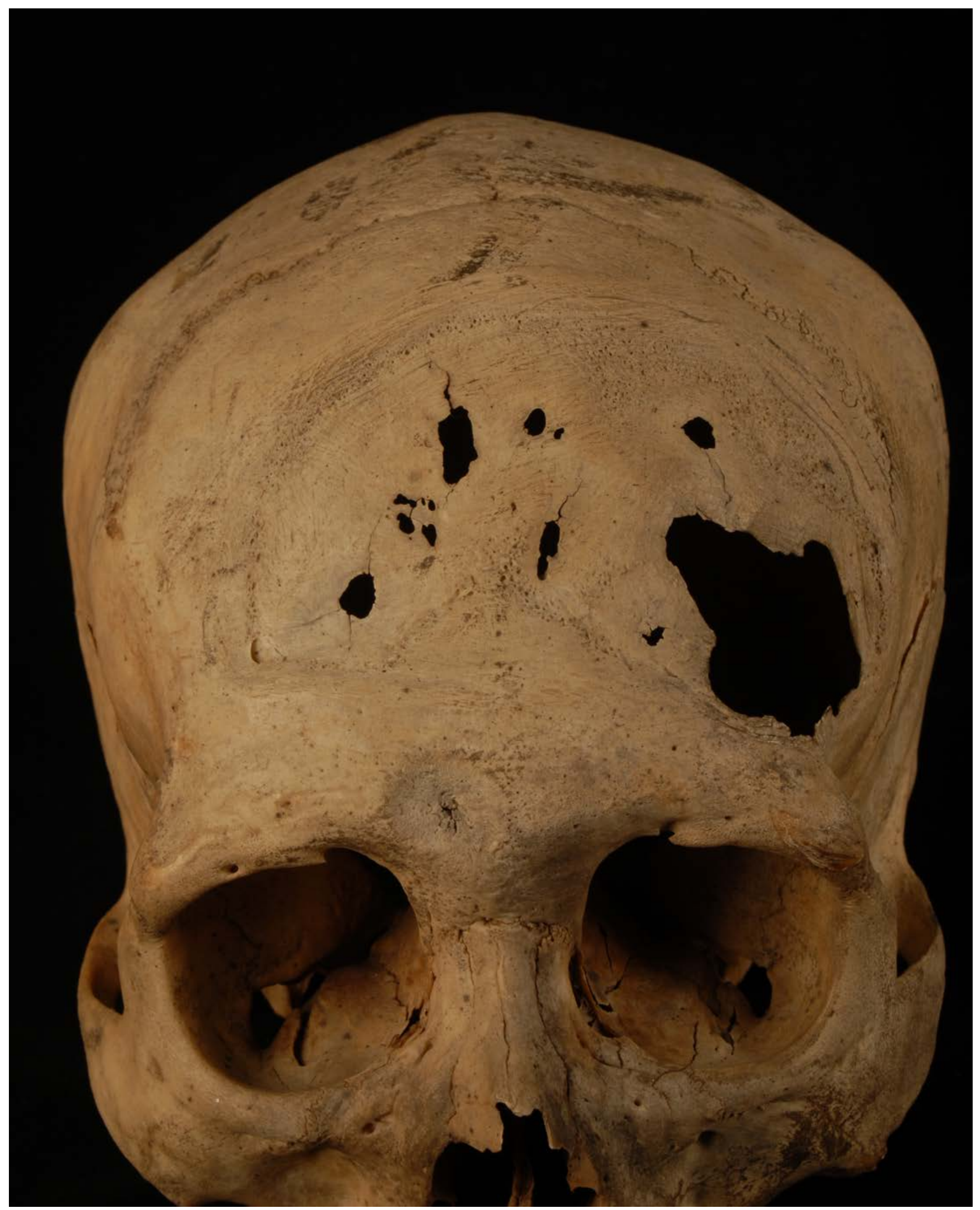


Figure 15

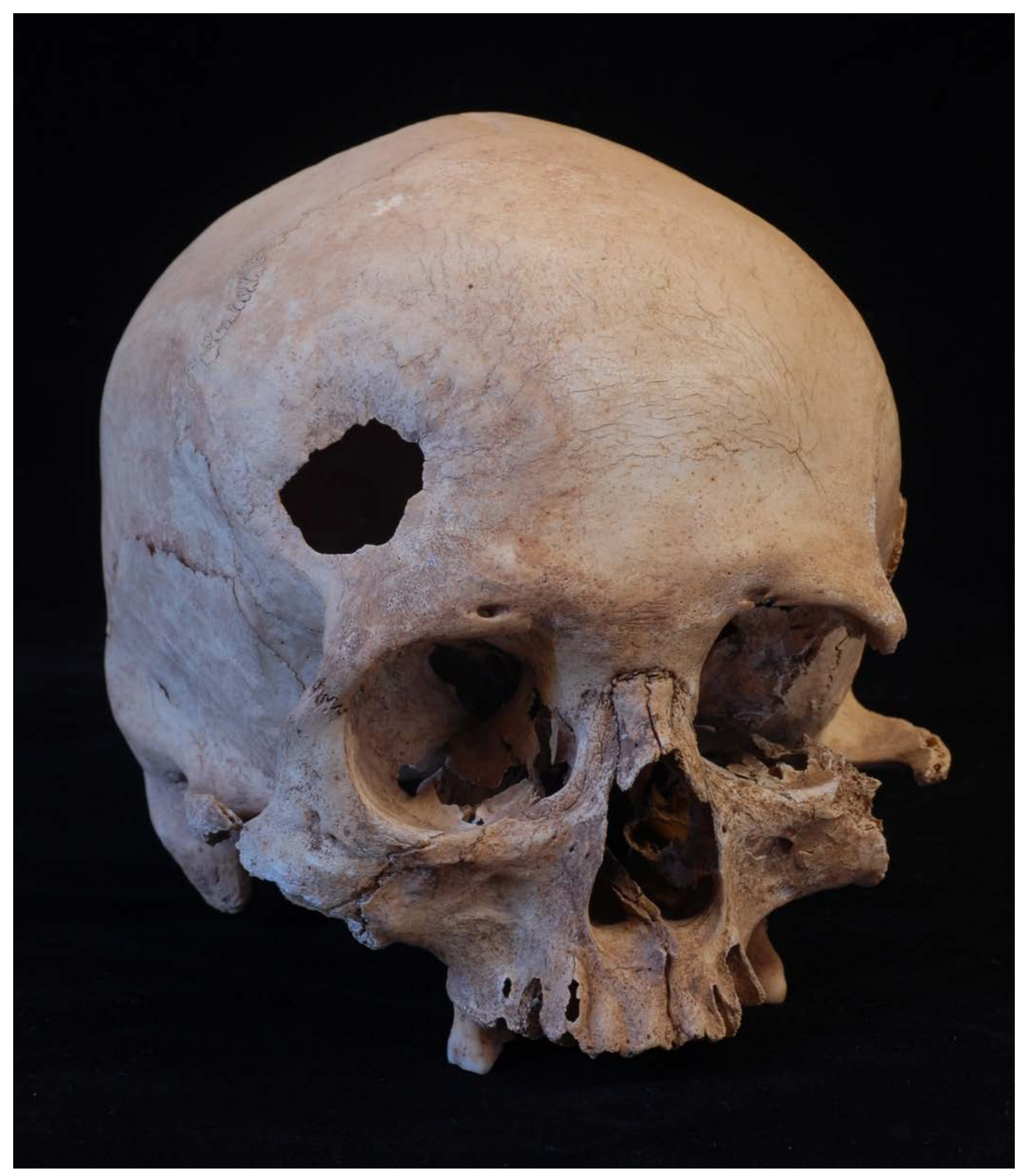

